\title{
Fuzzy Evaluation of Service Quality in The Banking
}

\author{
Endang suprihatin ${ }^{1}$ \\ Department of Industrial Engineering \\ University of 17 Agustus 1945 \\ Banyuwangi, Indonesia \\ 1endanguntagbwi@gmail.com
}

\author{
Rachmad Hidayat ${ }^{2}$ \\ Department of Industrial Engineering \\ University of Trunojoyo Madura \\ Bangkalan, Indonesia \\ ${ }^{2}$ rachmad.hidayat@trunojoyo.ac.id
}

\begin{abstract}
The measurement of banking service quality was done by Fuzzy servqual method. Service quality used five dimensions contained in servqual was tangible, reliability, responsiveness, assurance, emphaty. The results of this study indicated that the gap value of the five dimensions had a negative value. It means that the quality of service got was not in accordance with the expectation of the customer. The highest gap value was the dimension of responsiveness and the lowest gap was the dimension of reliability. Thus it can be seen that the dimensions of responsiveness were a concern to improve service quality. One variable that had a positive value was Customer Service variable who helps customer need.
\end{abstract}

Keywords-fuzzy servqual; service quality; responsiveness; reliability

\section{INTRODUCTION}

The customer is the main focus in the discussion of service satisfaction and quality. Therefore, customer plays an important role in measuring the satisfaction of products and services provided by the company. Customer satisfaction as the feeling of pleasure or disappointment of someone who emerged after comparing the perception or the impression of product performance and the expectation [1]. Consumer satisfaction is the difference between the level of importance and performance or perceived results [2]. Service quality is reflected in customer satisfaction to re-use banking services. Customer satisfaction in using the services or products offered can be used as input for the management to improve and to fix the service quality provided [3]. For that, the employee service unit should always monitor the satisfaction felt by banking customers to achieve loyalty from customers.

The intensity of competition and an increasing number of competitors so that banks are challenged to always pay attention to the needs and desires of consumers. Banks are required to meet consumer expectations by providingmore satisfactory service than competitors do. Banks are able to provide quality services that can compete and dominate the market. Quality has a close relationship with customer satisfaction [4]. Service quality problems that often become customer complaints to customer service include less rapid service [5-7], less friendly [8] and less customer satisfaction [9], and too rushed when serving customer [10].

According to Mohammad and Alhamadani [11], the components of satisfaction in the banking are: (a) Tangible, is physical evidence that must be owned by a bank employee, such as buildings, office supplies, employee appeal, communication and other physical facilities. Therefore, this physical evidence must be attractive and modern. (b) Responsiveness, namely the willingness of bank employees in giving services to customers. For that, the bank management needs to give great motivation for all bank employees to support the service activities to customers indiscriminately. Will support service activities to customers indiscriminately. It would be better if the motivation given to an employee will be rewarded according to his ability. (c) Assurance, the assurance that the employee has the knowledge, competence, courtesy and credible nature or behavior. This is important for the customer to be confident that their transactions are right and on target. (d) Reliability, namely the ability of banks in giving services that have been promised quickly, accurately and satisfy customers. In order to support this, every employee of the bank is otherwise given training and education in order to improve his/her abilities. (e) Empathy, which is able to provide convenience and establish relationships with customers effectively. Then also able to understand the individual needs of each customer quickly and appropriately. In this case the problem of work procedures associated with the level of service to customers.

Bank Mandiri is succesful in making service excellence as part of a consistently applied and sustainable corporate culture. This achievement becomes a pride, as well as a challenge to be able to maintain and even improve the quality of service. Bank Mandiri continues to develop employee competencies by developing customer service delivery processes. Bank Mandiri also continues to improve the performance of information technology that can support various service innovations to accelerate the process, making it easier for customers to transact. The purpose of this study was to determine the level of customer satisfaction using banking services. Fuzzy servqual is a fuzzy set theory that serves as a means of presenting uncertainty and is a tool for modeling uncertainties related to disguise, uncertainty and lack of information relating to specific elements and problems encountered [12].

\section{METHOD}

The population in this study were all Bank Mandiri customers who did the transaction in Bangkalan Branch Office. To determine the number of samples, researchers used the opinion of Slovin [13] namely: 


$$
n=\frac{N}{1+N \cdot e^{2}}=\frac{31201}{31200.1^{2}}=96.894 \approx 100 \text { Customers }
$$

Description:

$n=$ Sample

$N=$ Sample population

$e=$ error $10 \%$

In order to obtain more accurate data results, then the number of respondents who will be sampled and fulfilled to 100 customers.
The analytical method used was Fuzzy Servqual Analysis [14], to see how far the difference between expectation and performance or perception of the customer for service perceived by the customer. Service quality measurements in the servqual model were based on multi-item scales designed to measure service quality in five key dimensions and to gauge bank customers' expectations and perceptions, and the gaps between them in the five main servqual dimensions (Tangible, Reliability, Responsiveness, Assurance, and Empathy). The five main dimensions were translated into each question for the service quality variable arranged in questions based on the likert scale of 1 to 5 such as Table 1 .

TABLE I. RESEARCH VARIABLE GRID

\begin{tabular}{|c|c|c|}
\hline $\begin{array}{c}\text { Quest } \\
\text { Number }\end{array}$ & $\begin{array}{c}\text { Servqual } \\
\text { Dimention }\end{array}$ & Service Quality Variable Statement \\
\hline $\begin{array}{l}\text { Q1 } \\
\text { Q2 } \\
\text { Q3 } \\
\text { Q4 } \\
\text { Q5 }\end{array}$ & Tangible & $\begin{array}{l}\text { Comfort Building and Room } \\
\text { Facilities that meet the need } \\
\text { Employee use the neat and clean clothing } \\
\text { Strategic location } \\
\text { Customer Service Helps customer's need }\end{array}$ \\
\hline $\begin{array}{l}\text { Q6 } \\
\text { Q7 } \\
\text { Q8 } \\
\text { Q9 } \\
\text { Q10 }\end{array}$ & Reliability & $\begin{array}{l}\text { Employee ability to the service } \\
\text { Giving comfort service } \\
\text { Giving fast and on time service } \\
\text { Employee attitude gives the customer trust } \\
\text { Employee serves the customer needs }\end{array}$ \\
\hline $\begin{array}{l}\text { Q11 } \\
\text { Q12 } \\
\text { Q13 } \\
\text { Q14 } \\
\text { Q15 }\end{array}$ & Responsiveness & $\begin{array}{l}\text { Employee serves in accorance with customer wants } \\
\text { Get enough time in service } \\
\text { Giving accurate information } \\
\text { Always give help complain to service } \\
\text { Ready to respond customer request }\end{array}$ \\
\hline $\begin{array}{l}\text { Q16 } \\
\text { Q17 } \\
\text { Q18 } \\
\text { Q19 } \\
\text { Q20 }\end{array}$ & Assurance & $\begin{array}{l}\text { Give the satisfication of service } \\
\text { Thoroughness in serving } \\
\text { Having good knowledge about service } \\
\text { Having the ability to answer the question } \\
\text { Understand to the problem happended }\end{array}$ \\
\hline $\begin{array}{l}\text { Q21 } \\
\text { Q22 } \\
\text { Q23 } \\
\text { Q24 } \\
\text { Q25 }\end{array}$ & Empathy & $\begin{array}{l}\text { Having Familiy sense to the customer } \\
\text { Speech and speak well } \\
\text { Providing an understanding of the problem to the customer } \\
\text { Give priority to customer's interest in serving } \\
\text { Raise customers well if you make a mistake }\end{array}$ \\
\hline
\end{tabular}

\section{RESULTS AND DISCUSSION}

The first stage of this research was data preparation, which was obtained from 100 customers. The data obtained was the questionnaire data from 25 attribute questions that had been grouped into 5 servqual dimensions

\section{A. Fuzzy Alghoritm of Service Quality}

The first step was converting the scale value into the fuzzy number of input variables to each attribute. Determination of fuzzy sets such as Figure 1.

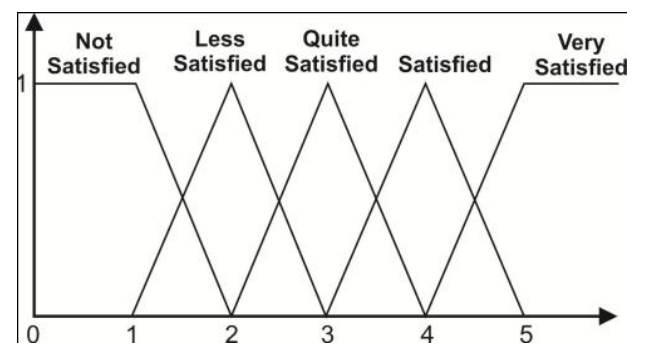

Fig. 1. Fuzzy Set
TABLE II. LIKERT SCALE INTERPRETATION

\begin{tabular}{|c|c|}
\hline Likert Scale & Fuzzy Number \\
\hline 1 & $(1,1,2)$ \\
2 & $(1,2,3)$ \\
3 & $(2,3,4)$ \\
4 & $(3,4,5)$ \\
5 & $(4,5,5)$ \\
\hline
\end{tabular}

In the interpretation, when the respondent chose a value of 4 (satisfied), it means that he considered, that 3 and 5 were the minimum and maximum values (or can be interpreted, that respondents consider which of the three hypotheses, plain, satisfied and highly satisfied that they find most representative). In the fuzzy method, a score of 4 corresponds to a value of $(3,4,5)$. Similarly, the score 5 corresponds to $(4$, $5,5)$ to obtain a fuzzy number of each value, such as Table 2.

After the conversion was done then the next process of composition fuzzy number $(a, b m i, c m i)$ for the perception and expectation of each attribute by using the principle of arithmetic operations on the TFN set. This composition process was used to obtain the composition value of the fuzzy 
number of all respondents by using arithmetic mean to obtain average weight score:

$$
\begin{aligned}
a m & =\frac{a m 1+a m 2+a m 3 \ldots+a m i}{N} b m \\
& =\frac{b m 1+b m 2+b m 3 \ldots+b m i}{N} c m \\
& =\frac{c m 1+c m 2+\ldots+c m i}{N}
\end{aligned}
$$

The value of the fuzzy number composicomposition of attribute obtained, then as done deffuzzyfification process with the method of centroithe d to obtain the value of a single value of each attribute. By using the Center of Area method that will be formulated as follows:

$$
z=\frac{\int \mu(z) z d z}{\int \mu(z) d z}
$$

The process above was repeated until all the attributes that exist in the perception and expectation got a deffuzzification value or single singular value. The gap performance value was calculated from the difference between the deffuzzification value that exists between the perceptual variable score and the expected variable of each attribute. With the following formula:

$$
(\text { Gap })=(\text { Perception value }- \text { Expectation value })
$$

After the defuzzification process was done, then got a single value that was representative. Furthermore, the analysis included: (1) Analysis of performance/reality vices provided. (2) Analysis of student expectation to service. Gap analysis of service quality between performance/reality and expectations/ service for attribute and dimension.

\section{B. Discussion}

The result of the defuzzification value of each variable of perception and expectation. Table III. shows the results of data processing with Fuzzy Servqual method. And then also shows the Gap value by reducing the value of the perceptual variable with the expectation variable for each attribute of the question. So it can be easy to analyze customer satisfaction. Figure 2. shows the graph of each attribute of the question according to the gap value. The smallest value of the gap indicates a nonconformity between perceptions and student expectations.

TABLE III. FUZZIFICATION RESULT

\begin{tabular}{|c|c|c|c|c|c|c|c|c|c|c|}
\hline \multirow{2}{*}{$\begin{array}{c}\text { Quest } \\
\text { Number }\end{array}$} & \multicolumn{3}{|c|}{ TFN Perception } & \multicolumn{3}{c|}{ TFN expectation } & \multicolumn{3}{c|}{ Defuzzyfication } \\
\hline & $\boldsymbol{c}$ & $\boldsymbol{a}$ & $\boldsymbol{b}$ & $\boldsymbol{c}$ & $\boldsymbol{a}$ & $\boldsymbol{b}$ & Perception & Expectation & Gap & Rank \\
\hline Q1 & 6.44 & 7.94 & 9.44 & 7.08 & 8.58 & 10.08 & 8.69 & 9.33 & -0.64 & 22 \\
Q2 & 6.56 & 8.06 & 9.56 & 7.02 & 8.52 & 10.02 & 8.81 & 9.27 & -0.46 & 16 \\
Q3 & 6.66 & 8.16 & 9.66 & 7.04 & 8.54 & 10.04 & 8.91 & 9.29 & -0.38 & 13 \\
Q4 & 6.80 & 8.30 & 9.80 & 7.32 & 8.82 & 10.32 & 9.05 & 9.57 & -0.52 & 18 \\
Q5 & 6.80 & 8.30 & 9.80 & 6.74 & 8.24 & 9.74 & 9.05 & 8.99 & 0.06 & 1 \\
\hline Q6 & 6.46 & 7.96 & 9.46 & 6.92 & 8.42 & 9.92 & 8.71 & 9.17 & -0.46 & 17 \\
Q7 & 6.40 & 7.90 & 9.40 & 7.16 & 8.66 & 10.16 & 8.65 & 9.41 & -0.76 & 24 \\
Q8 & 6.50 & 8.00 & 9.50 & 6.72 & 8.22 & 9.72 & 8.75 & 8.97 & -0.22 & 8 \\
Q9 & 6.62 & 8.12 & 9.62 & 7.00 & 8.50 & 10.00 & 8.87 & 9.25 & -0.38 & 14 \\
Q10 & 6.74 & 8.24 & 9.74 & 7.28 & 8.78 & 10.28 & 8.99 & 9.53 & -0.54 & 19 \\
\hline Q11 & 6.54 & 8.04 & 9.54 & 6.68 & 8.18 & 9.68 & 8.79 & 8.93 & -0.14 & 3 \\
Q12 & 6.92 & 8.42 & 9.92 & 7.14 & 8.64 & 10.14 & 9.17 & 9.39 & -0.22 & 9 \\
Q13 & 6.86 & 8.36 & 9.86 & 7.00 & 8.50 & 10.00 & 9.11 & 9.25 & -0.14 & 4 \\
Q14 & 6.94 & 8.44 & 9.94 & 6.94 & 8.44 & 9.94 & 9.19 & 9.19 & 0 & 2 \\
Q15 & 6.70 & 8.20 & 9.70 & 7.24 & 8.74 & 10.24 & 8.95 & 9.49 & -0.54 & 20 \\
\hline Q16 & 6.42 & 7.92 & 9.42 & 7.00 & 8.50 & 10.00 & 9 & 9.25 & -0.25 & 11 \\
Q17 & 6.48 & 7.98 & 9.48 & 7.28 & 8.78 & 10.28 & 8,72 & 9.53 & -0.81 & 25 \\
Q18 & 6.44 & 7.94 & 9.44 & 6.68 & 8.18 & 9.68 & 8.69 & 8.93 & -0.24 & 10 \\
Q19 & 6.56 & 8.06 & 9.56 & 7.14 & 8.64 & 10.14 & 8.81 & 9.39 & -0.58 & 21 \\
Q20 & 6.66 & 8.16 & 9.66 & 7.00 & 8.50 & 10.00 & 8.91 & 9.25 & -0.34 & 12 \\
\hline Q21 & 6.80 & 8.30 & 9.80 & 6.94 & 8.44 & 9.94 & 9.05 & 9.19 & -0.14 & 5 \\
Q22 & 6.80 & 8.30 & 9.80 & 7.00 & 8.50 & 10.00 & 9.05 & 9.25 & -0.2 & 7 \\
Q23 & 6.80 & 8.30 & 9.80 & 6.96 & 8.46 & 9.96 & 9.05 & 9.21 & -0.16 & 6 \\
Q24 & 6.46 & 7.96 & 9.46 & 6.86 & 8.36 & 9.86 & 8.71 & 9.11 & -0.4 & 15 \\
Q25 & 6.40 & 7.90 & 9.40 & 7.08 & 8.58 & 10.08 & 8.65 & 9.33 & -0.68 & 23 \\
\hline
\end{tabular}




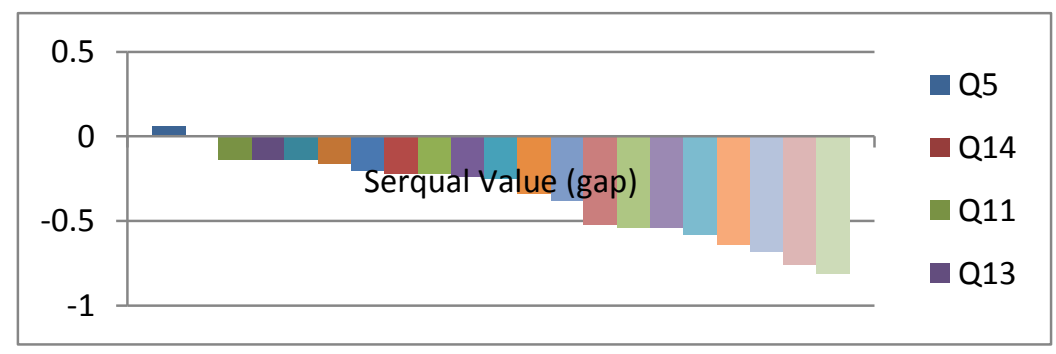

Fig. 2. Servqual value (gap)

Calculation of Servqual (Gap) Values each Attribute between Perceptions and Expectations of bank customers. The following are 5 variables or criteria with the biggest servqual value that should be the bank's attention. From the order of 5 above criteria that need to get more attention and evaluation of improvements from the bank, because the five criteria were perceived less by the customers. In table IV, it can be seen that the average of gap result from perception and expectation had negative value, there is only one statement variable that has a positive value that is the 5th statement of the statement (Customer Service helps customer need), with gap value 0.06. From this, it can be concluded that the customer had not been satisfied with the 18 variable statement, and only one variable that had reached the level of customer satisfaction.

Calculation of Servqual Value (Gap) each Dimension between Customer's Perception and Expectation as Table V. The gap per dimension calculation results shows that Dimension Responsiveness ranked first with a value of -1.04. This suggests that the criteria in the Responsiveness Dimension are necessary or prioritized for improvement. After processing data on each dimension, from the table above can be seen that all dimensions have a negative value. The first rank was the Responsiveness dimension with the gap value of -1.04 , then in the second rank was Empathy dimension with gap value of -1.58 , the third rank was Tangible dimension with gap value -1.94, the fourth rank was Assurance dimension with gap value of -2.22 , and fifth was Reliability dimension with gap value of -2.36 . From the data, it can be concluded that the overall dimension has not met the expectations of bank customers. Thus the priority dimension to be improved was the Responsiveness dimension.

TABLE IV. Average Of Gap Result From PERCEPTION AND EXPECTATION

\begin{tabular}{|c|l|c|}
\hline No. & \multicolumn{1}{|c|}{ Variable } & Gap \\
\hline 1. & Customer Service Helps customer's need & 0.06 \\
2. & Always give help complain to service & 0 \\
3. & Employee serves in accorance with customer wants & $-0,14$ \\
4. & Giving accurate information & $-0,14$ \\
5. & Having Familiy sense to the customer & -0.14 \\
\hline
\end{tabular}

TABLE V. SERVQUAL (GAP) EACH DIMENSION

\begin{tabular}{|c|l|c|}
\hline No. & \multicolumn{1}{|c|}{ Serqual Dimention } & Gap \\
\hline 1. & Responsiveness & -1.04 \\
2. & Empathy & -1.58 \\
3. & Tangible & -1.94 \\
4. & Assurance & -2.22 \\
5. & Reliability & -2.36 \\
\hline
\end{tabular}

\section{Managerial Implication}

In the banking, this responsiveness needs to be applied not only in the business world but also in interacting with others in the daily social system. The application in the banking is a front-liner service in the bank. A Customer Service in serving customers who come to the bank to transact or obtain information. Responsiveness, in general, is a desire to help, how to provide fast service, handling problems or complaints well and responsive to customer needs. Advancements in various fields supported by the sophistication of the communications media, unconsciously these have led to existing in conditions of high comfort levels. So if in certain circumstances facing inconvenience it will quickly react because it is not satisfied. Responsiveness to customer needs is a very important factor in serving customers.

Some activities that can be done to serve customers with responsive namely: (1) Immediately stand up to welcome customers and say greeting: "Good morning, can I help you ?". (2) Serving customers quickly, focus, not doing other works. (3) Ask the person's name and use the name when communicating. (4) Respond to customer complaints immediately and provide solutions according to the problems faced. (5) Avoid to say "I don't know ..." or "Well, this is not my business ...", and similar entences that can make customers feel there is no solution. (6) Immediately pick up the phone before the third ring (for communication over the phone)

In the implementation, there are often obstacles that cause inconsistencies in responding to customers well. Occurrence at a bank where the Customer Service officer visited by a prospective customer, the customer office is busy doing other work and does not directly serve the customer. A dissatisfied customer with reponsiveness leave the bank and cancel their plans to open an account and put some funds in the bank. To reduce the possibility of losses due to not responsive to the customer, it must be done by the bank are : (a) Have an attitude that every customer who comes need to be assisted to meet their needs. (b) Prepare and make sure that all of the process flow of service activities work properly. (c) If the job is very dependent on the system or technology, prepare a backup scenario if there is a problem with the technology (power failure, system drop, equipment not working, etc.). (d) Create a service level for the stages of your work, to avoid delays in providing services. (e) Prepare system control to keep it responsive to customers. (f) Use time well. 


\section{CONCLUSION}

Based on the results of research it can be concluded that based on the measurement of the five dimensions of service quality obtained all dimensions had negative value. Thus what is expected by customers to banking service was not in accordance with the reality received in the service. In these five servqual dimensions, the highest gap value was Responsiveness dimension and the lowest gap was Reliability dimension. From these results, the dimension of Responsiveness was a concern for banks to improve the quality of service. From the gap value per statement variable in the service quality dimension, there is only one value that has a positive value that is the 5th statement, Customer Service helps the customer needs. From this, it can be concluded that 24 other variable statements had not reached the level of customer satisfaction.

\section{REFERENCES}

[1] P. Kotler and G. Armstrong, Principles of marketing. London: Pearson education, 2010.

[2] Y. Ekinci, P.L. Dawes, and G.R. Massey, "An extended model of the antecedents and consequences of consumer satisfaction for hospitality services," Eur. J. of Mark., vol. 42, pp. 35-68, 2008.

[3] N. Chung and S.J. Kwon, "Effect of trust level on mobile banking satisfaction: a multi-group analysis of information system success instruments," Behav. and Inf. Technol., vol. 28, pp. 549-562, 2009.

[4] K.O. Siddiqi, "Interrelations between service quality attributes, customer satisfaction and customer loyalty in the retail banking sector in Bangladesh,” Int. J. of Bus. and Manag., vol. 6, pp. 12, 2011.
[5] C. Lu, et al., "Service quality and customer satisfaction: qualitative research implications for luxury hotels," Int. J. of Cult., Tour. and Hosp. Res., vol. 9, pp. 168-182, 2015.

[6] S. Sudin, "How service quality, value and corporate image affect client satisfaction and loyalty," [2nd International Research Symposium in Service Management, p. 116, 2011].

[7] T.S. Mian, "The Role of Service Quality in Developing Customer Loyalty in the Banking Sector: A Case study of the Kingdom of Saudi Arabia," Int. J. of Account. and Financ. Rep., vol. 4, pp. 339-360, 2014.

[8] A. Gupta and S. Dev, "Client satisfaction in Indian banks: an empirical study,” Manag. Res. Rev., vol. 35, pp. 617-636, 2012.

[9] L.L. Kheng, et al., "The impact of service quality on customer loyalty: A study of banks in Penang, Malaysia," Int. J. of Market. Stud., vol. 2, pp. $57,2010$.

[10] P. Mengi, "Customer satisfaction with service quality: An empirical study of public and private sector banks," IUP J. of Manag. Res., vol. 8, pp. 7, 2009 .

[11] A.A.S. Mohammad and S.Y.M. Alhamadani," Service quality perspectives and customer satisfaction in commercial banks working in Jordan,” Middle Eastern Financ. and Econ., vol. 14, pp. 60-72, 2011.

[12] R. Liu, et al., "Applying the fuzzy SERVQUAL method to measure the service quality in certification \& inspection industry," Appl. Soft Comput., vol. 26, pp. 508-512, 2015.

[13] J.J. Tejada and J.R.B. Punzalan, "On the misuse of Slovin's formula," The Philippine Statistician, vol. 61, pp. 129-136, 2012.

[14] M. Mashhadiabdol, S.M. Sajadi, and K. Talebi, "Analysis of the gap between customers' perceptions and employees' expectations of service quality based on fuzzy SERVQUAL logic (case study: Mofid children's hospital in Tehran, Iran), "Int. J. of Serv. and Oper. Manag., vol. 17, pp. 119-141, 2014. 